\title{
The Relationship Between Students' Physical Activity and Academic Stress
}

\author{
Laima Gasiūnienė, Brigita Miežienè \\ Lithuanian Sports University, Kaunas, Lithuania
}

\begin{abstract}
Background. Stress and physical inactivity are one of the most common risk factors among students. Problems of stress, experienced by students, and physical activity and impact on health are extremely important in order to improve students' quality of life and prevent health problems.

Methods. Academic stress was measured using the Konduri academic life stress questionnaire. Physical activity was evaluated by the Godin leisure time physical activity questionnaire. Distress was evaluated by the Reeder stress inventory. Study participants were 448 Lithuanian full-time first and third year bachelor's students, with ages ranging from 18 to 39 years; average age $20.06 \pm 18.04$. 38 percent (173) of people under investigation were women, and 62 percent (275) were men. 60 percent (268) of people under investigation were first-year students, 40 percent (180) were third-year students.

Results. Physically more active students experience less academic stress than less physically active students. Intense physical activity has the greatest impact on academic stress. Students who engage in intensive physical activity more often, experience less academic stress related to social support, motivation to achieve, training program and training mode, and self-confidence, compared with students who engage in intensive physical activity less often. It was found that women experience more academic stress, related to training program, academic aspirations, and career, compared with men. First-year students experience more academic stress, related to support, motivation to achieve, academic aspirations, self-confidence, and exam anxiety, compared with third-year students.

Conclusions. Half of all students go in for sports three or more times a week, a third of students go in for sports less than three times a week, almost one-fifth of students never go in for sports. Increased physical activity is among men, first-year students, compared with women and third-year students. A fifth of students experience stress, almost half of students experience nervous tension; one-third of students do not experience tension and stress. Higher stress, both general and related to academic activities, is felt by women and first-year students, compared with men and third-year students.
\end{abstract}

Keywords: students, physical activity, academic stress, stress.

\section{INTRODUCTION}

$\mathrm{T}$ The beginning of studies in high school is a significant life event - the stage of transition to adult life, which for the majority of people is full of anxiety and stress, because they need to adapt to the academic workloads and new educational, social and physical environment (Norkus \& Aluzas, 2012; Misra \& Castillo, 2004).
Therefore, students in institutions of high education, during the study year gain not only new experience, but experience and stress (Suresh et al., 2013; Dyson \& Renk, 2006). Results of scientific research show that one of the best ways to cope with stress, to improve psychical well-being, is physical activity (Cairney, Kwan, Veldhuizen \& Faulkner, 2014;

Copyright (C) 2021 Laima Gasiūnienė, Brigita Miežienė. Published by Lithuanian Sports University.

This is an Open Access article distributed under the terms of the Creative Commons Attribution 4.0 International License, which permits unrestricted use, distribution, and reproduction in any medium, provided the original author and source are credited. 
Boreham \& Riddoch, 2001). It was found that the mental health of physically more active students is better (Griniene, 2006). However, studying, because of its prevailing mental work and stressful situations, gives little time for physical activity. The authors note that the intensive and time-consuming mental work reduces the need for active physical activity and increases mental and nervous tension (Eller, Aluoja, Vasar \& Veldi, 2006).

Based on results of the scientific research, stress among students is widespread. According to Oswalt and Riddock (2007), 50 percent of students feel stress and 25 percent of students feel stress very strongly. Results of study performed by Karkockiene (2011), revealed that 50 percent of students from university and 38.5 percent of students from college often experience stress.

According to Eller et al. (2006), who analyzed students' well-being in many countries of the world, one of the health problems is symptoms of depression or depressive mood among students in Lithuania (Valinteliene et al., 2012; Poteriūniene, 2010; Vaščila et al., 2007), as well as in other countries (Stock et al., 2001; Kramer, PruferKramer, Stock \& Tshiananga, 2004; Bostanci Bostanci, Ozdel, Oguzhanoglu, Ozdel, Ergin, Ergin \& Karadag, 2005) where, due to the inability to combine sports exercises with studies, students' physical activity is insufficient.

Thus, physical inactivity and stress are among the most common risk factors among students. However, there is still a lack of studies which examine the relationship between the physical activity of students and stress (especially academic stress).

The aim of the study: To assess the relationship between students' academic stress and they physical activity.

The object of research: The relationship between students' academic stress and they physical activity.

\section{METHODS}

Organization of the study: In order to assess the intelligibility of the questionnaire in November and December 2013, an exploratory study was carried out. To evaluate the validity of questionnaires, measuring the stress (L. G Reeder and N. Konduri), in January and February 2014 retesting estimates stability was conducted (test-retest). In October and November 2014 an anonymous questionnaire survey was carried out.
Participants in the study involved 448 Lithuanian full-time first and third year bachelor's students. Sample quantity was calculated, using the sample formula, dependent on the general set (Kardelis, 2007). After calculation, it was found that the study sample size (with the margin of error, which is 0,05 ) is 399 . Thus, 448 respondents, who participated in study, are enough to represent the entire population, and the survey is representative. The age of people under investigation ranged from 18 to 39 years old, average age $20,06 \pm 18,04.38$ percent (173) of people under investigation were women, and 62 percent (275) of people under investigation were men. 60 percent (268) of people under investigation were first-year students, 40 percent (180) were third-year students.

Research methods: Distress was evaluated by the Reeder stress inventory which consists of seven statements describing well-being, each of which is evaluated on a scale from 1 to 4 . Scores of all seven statements are summed up, and the resulting overall score, which can range from 7 to 28 , shows the typical respondent level of perceived stress: at $21-28$, there is no stress; at $15-20$, there is nervous tension (intermediate state); 7-14 denotes a stressful condition. In this study reliability of the Reeder stress inventory is sufficient; Cronbach's alpha coefficient is 0.82 .

Academic stress measured using the Konduri academic life stress questionnaire which consists of 27 statements. In response to each of the statements, the respondents were asked to mark one of four possible options: "it is not stressful or there is no stress" - scores 1; "little stressful" - scores 2; "at an average stressful" - scores 3; "very stressful" scores 4 . The higher the result, the higher the level of subjectively perceived stress. In this paper reliability of the Konduri academic life stress questionnaire is sufficient; Cronbach's alpha coefficient is 0.89 . The Konduri questionnaire consists of seven factors: stress related to social support; stress related to achievements and motivation; stress related to training program and training regimen; stress related to academic aspirations; stress related to selfconfidence; stress related to exams/implementation anxiety; and stress related to career.

Physical activity was evaluated by the Godin leisure time physical activity questionnaire. Respondents were asked to indicate how often they engage in certain physical activity each week. Near each line, i.e. "Vigorous physical activity", "moderate physical activity", and "low physical 
activity", the person under investigation had to write how many times within 7 days in they own time they engage in indicated physical activity for longer than 15 minutes. Physical activity result is calculated by the following formula: Total physical activity $=(9 \mathrm{x}$ "Vigorous physical activity") + (5 x "moderate physical activity") $+(3 \mathrm{x}$ "low physical activity") (Kriska \& Caspersen, 1997). Respondents can score between 0 and 119, the higher number corresponding with greater physical activity. Godin scale score interpretation: 24 units or more - vigorous physical activity (PA); 14-23 units - moderate PA; lower than 14 units - low PA.

Physical activity was also evaluated by asking: Over a 7-day period, how often in your spare time do you engage in regular physical activity, artificially long before you sweat (heart beats fast)? The answer options were: Often (three times a week and more); Sometimes (less than 3 times a week); or, Never.

Statistical analysis: Statistical data analysis was performed, using SPSS 17.0 program of calculations. For comparison of frequencies the chi-square ( $\chi 2$ criterion) was used. Before using parametric statistical criteria distribution of scales, used in work, was specified according to the normal law. For evaluation coefficients of asymmetry and excess were used. The distribution was considered to be close to normal, when values of its coefficients of asymmetry and excess got into $-1-1$ interval. Mean comparison was performed, using Student's $\mathrm{t}$-criterion. The relationship between variables was calculated on the basis of hierarchical regression analysis, in which the blocks of independent variables were placed. In the first block, sociodemographic and indicators related to studies, were placed; in the second block the indicator measuring general stress was placed; in the third block the indicator measuring physical activity was placed. Internal reliability of scales was calculated on the basis of Cronbach's $\alpha$ criterion. The results were considered statistically significant, if the error probability value $\mathrm{p}<0.05$.

\section{RESULTS}

Physical activity. Analyzing physical activity of students, it was found that half of the respondents engage in regular physical activity often (three or more times a week), slightly more than one-third of respondents engage in physical activity sometimes (less than 3 times a week), while the remaining respondents never engage in physical activity (Fig. 1).

Fig. 1. Distribution of physical activity frequencies between men and women (in percent)

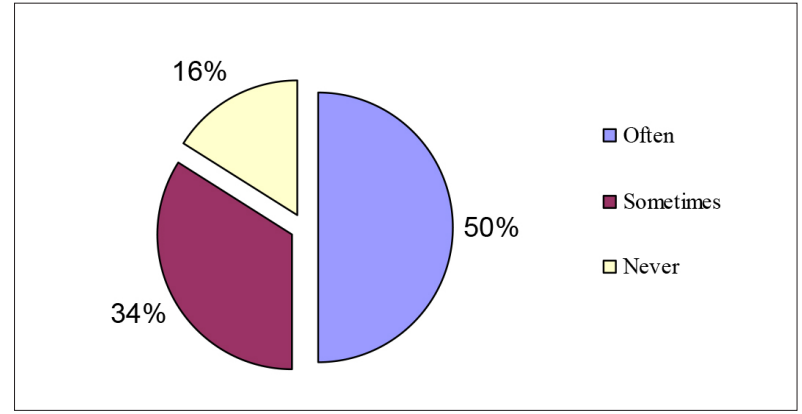

Comparing physical activity of students, gender and study year, statistically significant differences were found. Significantly more men reported going in for sports often, compared with women. Significantly more women reported never going in for sports, compared with men (Fig. 2). First-year students significantly more frequently stated going in for sports often, or never going in for sports, compared with third-year students. Among the third-year students significantly more respondents stated going in for sports sometimes, compared with first-year students (Fig. 2).
Fig. 2. Distribution of physical activity frequencies between men, women and study year (in percent)

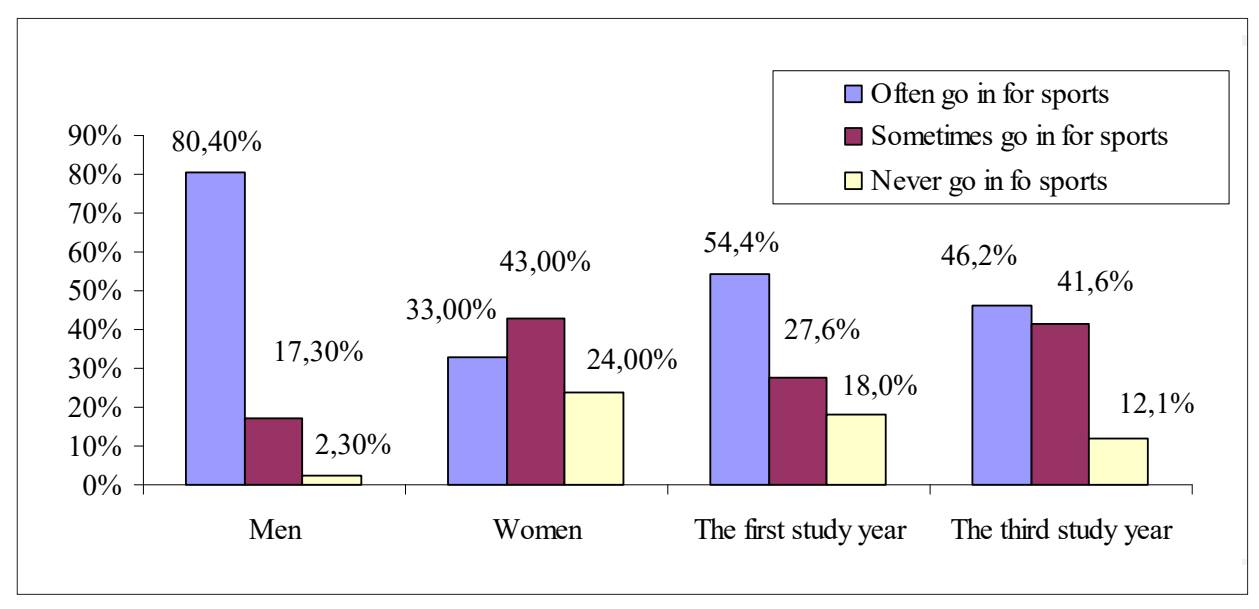


$\chi 2=96.685 ; 11 \mathrm{~s}=4 ; \mathrm{p}=0.001$

General and academic stress. Analysis results of stress show that slightly more than one-third of students do not suffer from stress and nervous tension; slightly more than a quarter of students suffer from nervous tension; and slightly more than two tenths of students suffer from stress (Fig. 3).

Fig. 3. Distribution of respondents according to the L.G. Reeder stress inventory (in percent)

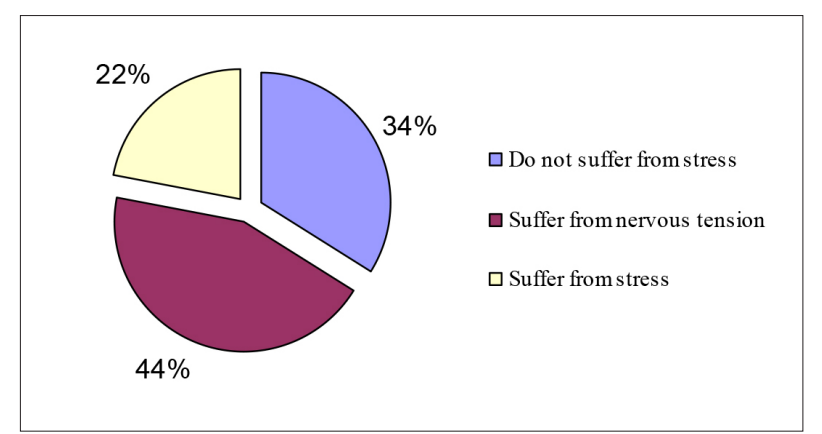

The results indicated that women and first-year students experience greater tension (Table 1).

Table 1. Comparison of general stress between gender and study year

\begin{tabular}{|c|c|c|c|c|}
\hline \multirow{5}{*}{$\frac{\tilde{E}}{0}$} & Name of variables & $\begin{array}{l}\text { Mean } \pm \text { standard } \\
\text { deviation }\end{array}$ & $\mathbf{t}$ & $\mathbf{p}$ \\
\hline & Man & $19.25 \pm 3.63$ & \multirow{2}{*}{3.381} & \multirow{2}{*}{0.001} \\
\hline & Woman & $17.76 \pm 4.88$ & & \\
\hline & The first study year & $17.82 \pm 4.76$ & \multirow{2}{*}{-3.036} & \multirow{2}{*}{0.003} \\
\hline & The third study year & $19.15 \pm 3.95$ & & \\
\hline
\end{tabular}

Analyzing academic stress experienced by students, we compared the averages of scores. It was found that women experience more academic stress, related to training program, academic aspirations, and career, compared with men (Table 2). First-year students experience more academic stress related to support, motivation to achieve, academic aspirations, self-confidence, and exams anxiety, compared with third-year students (Table 2).
Table 2. Comparison of academic stress between gender and the first and third-year students

\begin{tabular}{|c|c|c|c|c|}
\hline Academic stress & Gender and study year & Mean \pm standard deviation & $\mathbf{t}$ & $\mathbf{p}$ \\
\hline \multirow{4}{*}{$\begin{array}{l}\text { Social support - } \\
\text { related stress }\end{array}$} & Man & $7.75 \pm 3.08$ & \multirow{2}{*}{-1.699} & \multirow{2}{*}{0.090} \\
\hline & Woman & $8.37 \pm 4.09$ & & \\
\hline & The first & $8.76 \pm 4.03$ & \multirow{2}{*}{4.413} & \multirow{2}{*}{0.001} \\
\hline & The third & $7.19 \pm 3.06$ & & \\
\hline \multirow{4}{*}{$\begin{array}{l}\text { Achievements- } \\
\text { motivation - } \\
\text { related stress }\end{array}$} & Man & $6.27 \pm 2.28$ & \multirow{2}{*}{0.08} & \multirow{2}{*}{0.936} \\
\hline & Woman & $6.25 \pm 2.59$ & & \\
\hline & The first & $6.53 \pm 2.56$ & 2814 & 0005 \\
\hline & The third & $5.86 \pm 2.29$ & 2.814 & 0.005 \\
\hline \multirow{4}{*}{$\begin{array}{l}\text { Training } \\
\text { program - related } \\
\text { stress }\end{array}$} & Man & $8.79 \pm 2.52$ & \multirow{2}{*}{-2.619} & \multirow{2}{*}{0.009} \\
\hline & Woman & $9.58 \pm 3.34$ & & \\
\hline & The first & $9.21 \pm 3.2$ & 304 & 0604 \\
\hline & The third & $9.34 \pm 2.85$ & -3.94 & 0.694 \\
\hline \multirow{4}{*}{$\begin{array}{l}\text { Academic } \\
\text { aspirations - } \\
\text { related stress }\end{array}$} & Man & $8.76 \pm 2.69$ & \multirow{2}{*}{-2.749} & \multirow{2}{*}{0.006} \\
\hline & Woman & $9.70 \pm 3.92$ & & \\
\hline & The first & $9.94 \pm 3.84$ & 4440 & 0001 \\
\hline & The third & $8.45 \pm 2.74$ & 4.449 & 0.001 \\
\hline \multirow{4}{*}{$\begin{array}{l}\text { Self-confidence - } \\
\text { related stress }\end{array}$} & Man & $5.74 \pm 2.09$ & \multirow{2}{*}{-1.494} & \multirow{2}{*}{0.136} \\
\hline & Woman & $6.09 \pm 2.63$ & & \\
\hline & The first & $6.51 \pm 2.56$ & 6035 & 0001 \\
\hline & The third & $5.14 \pm 2.02$ & 0.053 & 0.001 \\
\hline \multirow{4}{*}{$\begin{array}{l}\text { Exams anxiety - } \\
\text { related stress }\end{array}$} & Man & $7.34 \pm 7.88$ & \multirow{2}{*}{-1.595} & \multirow{2}{*}{0.111} \\
\hline & Woman & $7.88 \pm 3.70$ & & \\
\hline & The first & $8.48 \pm 3.72$ & 6347 & 0001 \\
\hline & The third & $6.44 \pm 2.57$ & 0.347 & 0.001 \\
\hline \multirow{4}{*}{$\begin{array}{l}\text { Career - related } \\
\text { stress }\end{array}$} & Man & $5.7 \pm 1.91$ & \multirow{2}{*}{-3.346} & \multirow{2}{*}{0.001} \\
\hline & Woman & $6.49 \pm 2.72$ & & \\
\hline & The first & $6.21 \pm 2.68$ & 0465 & 0612 \\
\hline & The third & $6.10 \pm 2.08$ & 0.465 & 0.642 \\
\hline \multirow{4}{*}{$\begin{array}{l}\text { The overall } \\
\text { of entire } \\
\text { questionnaire }\end{array}$} & Man & $50.03 \pm 12.62$ & \multirow{2}{*}{-2.624} & \multirow{2}{*}{0.009} \\
\hline & Woman & $54.58 \pm 19.74$ & & \\
\hline & The first & $55.48 \pm 19.43$ & \multirow{2}{*}{3.958} & \multirow{2}{*}{0.001} \\
\hline & The third & $48.70 \pm 12.92$ & & \\
\hline
\end{tabular}


The relationship between stress, experienced by students, and physical activity

The relationship between stress, experienced by students, and physical activity was determined by dint of hierarchical regression analysis. The dependent variable is the academic stress. The main independent variable - physical activity. As relationship controlling factors, other independent variables were included: gender, study year, level of experienced stress (according to L. G Reeder scale).

Analyzing academic stress related to social support, it was found that variables of the first block explain 13.9 percent of dispersion of this particular stress. Statistically significant factors explaining academic stress related to social support in the first block are gender and study year. Female gender and the first year of study explain the greater academic stress related to social support. Variables of the second block explain in addition 17.6 percent of dispersion of academic stress, related to social support. In the second block placed the total experienced stress was significant. The greater level of experienced stress explains the greater academic stress related to social support. The study year remained significant, while gender lost significance. Significantly related to academic stress factors is the third block are study year, level of experienced stress and intense physical activity.
Table 3. Predictive factors of social support related stress

\begin{tabular}{|c|c|c|c|c|}
\hline Variable & Adjusted R & $\beta$ & $\mathbf{t}$ & $\mathbf{p}$ \\
\hline The first block $F(2)=16.593, p=0.001$ & 0.139 & & & \\
\hline Gender (woman) & & 0.107 & 2.326 & $\mathbf{0 . 0 2 0}$ \\
\hline Study year (the third) & & -0.316 & -6.648 & 0.001 \\
\hline The second block $F(3)=37.654, p=0.001$ & 0.315 & & & \\
\hline Gender (woman) & & 0.033 & 0.782 & 0.434 \\
\hline Study year (the third) & & -0.212 & -4.844 & 0.001 \\
\hline General stress & & -0.446 & -10.250 & 0.001 \\
\hline The third block $F(6)=24.240, p=0.001$ & 0.323 & & & \\
\hline Gender (woman) & & 0.001 & 0.009 & 0.993 \\
\hline Study year (the third) & & -0.214 & -4.891 & 0.001 \\
\hline General stress & & -0.444 & -10.192 & 0.001 \\
\hline Vigorous PA & & -0.093 & -1.929 & $\mathbf{0 . 0 4 4}$ \\
\hline Moderate PA & & 0.061 & 1.258 & 0.209 \\
\hline Low PA & & -0.055 & -1.201 & 0.230 \\
\hline
\end{tabular}

Table 4. Predictive factors of achievements and motivation related stress

\begin{tabular}{|c|c|c|c|c|}
\hline Variable & Adjusted R & $\boldsymbol{\beta}$ & $\mathbf{t}$ & p \\
\hline The first $F(2)=8.585, p=0.001$ & 0.069 & & & \\
\hline Gender (woman) & & 0.021 & 0.449 & 0.654 \\
\hline Study year (the third) & & -0.212 & -4.290 & 0.001 \\
\hline The second block $F(3)=16.423, p=0.001$ & 0.158 & & & \\
\hline Gender (woman) & & -0.035 & -0.756 & 0.450 \\
\hline Study year (the third) & & -0.135 & -2.792 & 0.005 \\
\hline General stress & & -0.320 & -6.644 & 0.001 \\
\hline The third block $F(6)=11.126, p=0.001$ & 0.164 & & & \\
\hline Gender (woman) & & -0.076 & -1.512 & 0.131 \\
\hline Study year (the third) & & -0.147 & -3.030 & 0.003 \\
\hline General stress & & -0.312 & -6.483 & 0.001 \\
\hline Vigorous PA & & -0.091 & -1.955 & 0.041 \\
\hline Moderate PA & & -0.046 & -0.852 & 0.395 \\
\hline Low PA & & -0.015 & -0.301 & 0.764 \\
\hline
\end{tabular}


Physical activity in addition explains 0.8 percent of dispersion of academic stress related to social support. Increased physical activity explains lower academic stress related to social support (Table 3).

Analyzing the stress related to achievements and motivation, it was found to be significantly related to the study year, stress and intense physical activity (Table 4). As can be seen in the third block, more intense physical activity explains in addition 0.6 percent of dispersion of academic stress, related to achievements and motivation (Table 4).

Analyzing academic stress, related to the training program and training regimen, it was found to be significantly related to stress and intense physical activity (Table 5). More intense physical activity explains an additional 0.14 percent of dispersion of academic stress, related to the training program and training regimen (Table 5).

Analyzing the academic stress related to selfconfidence, it was found to be significantly related to the study year, stress and intense physical activity (Table 6). As can be seen in the third block, more intense physical activity explains an additional 0.14 percent of dispersion of academic stress related to self-confidence (Table 6).
Table 5. The predictive factors of training program and regime related stress

\begin{tabular}{|c|c|c|c|c|}
\hline Variable & Adjusted R & $\boldsymbol{\beta}$ & $\mathbf{t}$ & $\mathbf{p}$ \\
\hline The first block $F(2)=8.868, p=0.001$ & 0.071 & & & \\
\hline Gender (woman) & & 0.107 & 2.230 & 0.026 \\
\hline Study year (the third) & & -0.061 & -1.234 & 0.218 \\
\hline The second block $F(3)=32.239, p=0.001$ & 0.276 & & & \\
\hline Gender (woman) & & 0.026 & 0.609 & 0.543 \\
\hline Study year (the third) & & 0.051 & 1.144 & 0.253 \\
\hline General stress & & -0.481 & -10.755 & 0.001 \\
\hline The third block $F(6)=22.172, p=0.001$ & 0.293 & & & \\
\hline Gender (woman) & & -0.027 & -0.586 & 0.558 \\
\hline Study year (the third) & & 0.042 & 0.939 & 0.348 \\
\hline General stress & & -0.472 & -10.661 & 0.001 \\
\hline Vigorous PA & & -0.142 & -2.880 & 0.004 \\
\hline Moderate PA & & 0.019 & 0.380 & 0.704 \\
\hline Low PA & & -0.087 & -1.850 & 0.065 \\
\hline
\end{tabular}

Table 6. Predictive factors of self-confidence related stress

\begin{tabular}{|c|c|c|c|c|}
\hline Variable & Adjusted R & $\beta$ & $\mathbf{t}$ & $\mathbf{p}$ \\
\hline The first block $F(2)=13.830, p=0.001$ & 0.11 & & & \\
\hline Gender (woman) & & 0.094 & 2.017 & 0.044 \\
\hline Study year (the third) & & -0.326 & -6.780 & 0.001 \\
\hline The second block $F(3)=35.803, p=0.001$ & 0.295 & & & \\
\hline Gender (woman) & & 0.018 & 0.423 & 0.672 \\
\hline Study year (the third) & & -0.220 & -5.007 & 0.001 \\
\hline General stress & & -0.457 & -10.447 & 0.001 \\
\hline The third block $F(6)=24.146, p=0.001$ & 0.309 & & & \\
\hline Gender (woman) & & -0.039 & -0.855 & 0.393 \\
\hline Study year (the third) & & -0.230 & -5.255 & 0.001 \\
\hline General stress & & -0.451 & -10.384 & 0.001 \\
\hline Vigorous PA & & -0.149 & -3.085 & 0.002 \\
\hline Moderate PA & & 0.025 & 0.524 & 0.601 \\
\hline Low PA & & -0.050 & -1.096 & 0.274 \\
\hline
\end{tabular}




\section{DISCUSSION}

This paper aimed to evaluate the relationship between academic stress and physical activity. The study found that physical activity is significantly related to academic stress. Physically more active students experience less academic stress, compared with less physically active students. In researching the impact of physical activity intensity on academic stress, it was found that intense physical activity has the greatest impact on academic stress. Students who more often engage in intense physical activities experience less academic stress, related to social support, achievements and motivation, training program and training regimen, and selfconfidence, compared with students, who engage less often in intense physical activity.

Other researchers, who examined the relationship between physical activity and stress, also found that physical activity positively affects psychological human health. Nguyen-Michel, Unger, Hamilton, Spruijt-Metz, (2006) researched the relationship between physical activity of students and perceived stress and found that physically active students experience less stress. Lochbaum, Lutz, Sell, Ready and Carson (2004) found that physically more active students less often experience physical and mental health complaints. Griniene (2006) revealed that the mental health, related to studies, of physically more active students, is better. Brown and Blanton (2002) researched the physical activity of students, participation in sports and suicidal behavior, and found that physically more active students experience less stress, and they are less prone to suicidal behavior. A number of studies revealed that physical activity is an effective tool for reducing stress and improving mental health (Cairney et al., 2014; Dunn, Trivedi \& O'Neal, 2001; Fontaine, 2000).

Analyzing physical activity and stress from a gender perspective, it was found that female students experience greater stress and academic stress compared with male students. It was also found that male students are more physically active, and they physical activity is higher compared with female students. The obtained results confirm a number of other studies which indicate that male students are more physically active than female students (Bergier \& Wojtyla, 2012; Grinienè, 2006). Also, female students experience more academic stress than male students (Balkishan et al., 2011; Gadzella, Pierce \&Young, 2008; Goštautas, Grigaitė \& Klasavičienè, 2004).
In this study, examining the relationship between academic stress, gender, and physical activity, it was found that female gender lowers physical activity and predicts higher academic stress.

Smith and Lynch (2012), who studied the relationship between physical activity and mental health, argue that physical exercise increases the amount of steroids, which have stress-reducing effects. During exercise, the body releases endorphins, neuropeptides that bind to opioid receptors in the brain and have analgesic effects. These hormones cause a full range of positive effects: improved mood, cognitive ability, pain reduction, regulated blood pressure, and improved breathing and digestion, all favorable for the immune system. Changes caused by physical activity improve cognitive functions and psychological status: they reduce anger, anxiety, but also promote structural adaptation in the brain (Booth, Moseley, Schiltenwolf \& Hübscher, 2017). Better psychoemotional well-being is also thought to be due to the fact that physical activity distracts people from depressing thoughts and stressors. Zschucke et al. (2015) state that strong physical activity alters the brain's response to strong stressors and affects cortisol secretion. It has been found that the amount of the stress hormone cortisol released in the stressful situation of athletes is lower than in people who are less physically active. Consequently, high physical activity can be beneficial in reducing stress (Basso \& Suzuki, 2017).

Thus, the results of the study show that physical activity is related to lower stress experienced during studies. Therefore, in universities it should be relevant to involve students in active physical practice, to create conditions to enhance health, using physical education and engagement in sports, to eliminate the deficit in physical exercise, to improve physical training, and to help in the development of training and practice of sports skills. Foreign researchers already demonstrated that the beginning of high school studies is a favorable time to change lifestyle habits of students (Gayles \& Hu, 2009), so Lithuanian high schools should use this opportunity.

Based on the results of this study more attention should be paid to first-year and female students. Physical activity should be encouraged and opportunities to be physically active at the university campus should be provided, as physically active students experience less academic and general stress. 


\section{CONCLUSION}

Half of all students go in for sports three or more times a week, a third of students go in for sports less than three times a week, almost onefifth of students never go in for sports. Greater physical activity is among men and first-year students, compared with women and third-year students. A fifth of students experience stress and almost half of students suffer from nervous tension; one-third of students do not suffer from tension and stress. Higher general stress, and stress related to academic activities, is felt by women and firstyear students, compared with men and third-year students. Students who engage in intense physical activity more often, experience less academic stress - related to social support, achievements and motivation, training program and regime, and selfconfidence - compared with students who engage in intense physical activity less often.

\section{REFERENCES}

Basso, J. C., \& Suzuki, W. A. (2017). The effects of acute exercise on mood, cognition, neurophysiology, and neurochemical pathways: a review. Brain Plasticity, 2(2), 127-152. doi: https://doi.org/10.3233/BPL-160040

Bergier, B., Bergier, J., \& Wojtyla, A. (2012). Various aspects of physical activity among Lithuanian adolescents. Annals of agricultural and environmental medicine, 19(4), 775-779. Retrieved from http:// citeseerx.ist.psu.edu/viewdoc/download?doi=10.1.1.992 $.7376 \&$ rep $=$ rep $1 \&$ type $=$ pdf

Booth, J., Moseley, G. L., Schiltenwolf, M., Cashin, A., Davies, M., \& Hübscher, M. (2017). Exercise for chronic musculoskeletal pain: a biopsychosocial approach. Musculoskeletal care, 15(4), 413-421. doi: https://doi.org/10.1002/msc.1191

Boreham, C., \& Riddoch, C. (2001). The physical activity, fitness and health of children. Journal of sports sciences, 19(12), 915-929. doi: https://doi. org/10.1080/026404101317108426

Bostanci, M., Ozdel, O., Oguzhanoglu, N. K., Ozdel, L., Ergin, A., Ergin, N., ... \& Karadag, F. (2005). Depressive symptomatology among university students in Denizli, Turkey: prevalence and sociodemographic correlates. Croatian Medical Journal, 46(1), 96-100.

Brown, D. R., \& Blanton, C. J. (2002). Physical activity, sports participation, and suicidal behavior among college students. Medicine \& Science in Sports \& Exercise, 34(7), 1087-1096. doi: https://doi.org/10.1097/00005768200207000-00006

Cairney, J., Kwan, M. Y., Veldhuizen, S., \& Faulkner, G. E. (2014). Who uses exercise as a coping strategy for stress? Results from a national survey of Canadians. Journal of Physical Activity and Health, 11(5), 908-916. doi: https://doi.org/10.1123/jpah.2012-0107

Dyson, R., \& Renk, K. (2006). Freshmen adaptation to university life: Depressive symptoms, stress, and coping. Journal of clinical psychology, 62(10), 12311244. doi: https://doi.org/10.1002/jclp.20295

Dunn, A.L., Trivedi, M.H., \& O’Neal, H.A. (2001). Physical activity dose-response effects on outcomes of depression and anxiety. Medicine \& Science in
Sports \& Exercise, 33(6), 587-610. doi: https://doi. org/10.1097/00005768-200106001-00027

Eller, T., Aluoja, A., Vasar, V., \& Veldi, M. (2006). Symptoms of anxiety and depression in Estonian medical students with sleep problems. Depress Anxiety, 23(4), 250-256. doi: https://doi.org/10.1002/da.20166

Fontaine, K. R. (2000). Physical activity improves mental health. The Physician and sportsmedicine, 28(10), 8384. doi: https://doi.org/10.3810/psm.2000.10.1256

Gadzella, B. M., Pierce, D., \& Young, A. A. (2008). Development and analyses of the Coping Stress Inventory. College Student Journal, 42(2), 254-264.

Gayles, J. G., \& Hu, S. (2009). The influence of student engagment and sport participation on college outcomes among division I student athletes. The Journal of Higher Education, 80(3), 315-333. doi: https://doi.org/10.1080/ 00221546.2009 .11779015

Goštautas, A., Grigaitė, B., \& Klasavičienè, R., (2004). Kolegijosstudentųsavęs vertinimoypatumai.Pedagogika, 74, 33-37. Retrieved from http://etalpykla.lituanistikadb.lt/ fedora/objects/LT-LDB-0001:J.04 2004 1367176541216/ datastreams/DS.002.0.01.ARTIC/content

Grinienè, E. (2006). Studentų savos sveikatos vertinimas ir požiūris ì sveiką gyvenseną. Baltic Journal of Sport and Health Sciences, 1(60), 10-17. doi: https://doi. org/10.33607/bjshs.v1i60.601

Kardelis, K. (2007). Mokslinių tyrimų metodologija ir metodai (edukologija ir kiti socialiniai mokslai). Vadovèlis. Šiauliai: Liucilijus.

Karkockienè, D. (2011). Medicinos ir sveikatos mokslų studentu patiriamo streso ypatumai ir jo itaka miego kokybei. Visuomenès sveikata, 2(53), 83-92. Retrieved from https://hi.lt/uploads/pdf/visuomenes $\% 20$ sveikata/2011.2(53)/VS 20112 2(53) Karkockiene.pdf

Kramer, A., Prufer-Kramer, L., Stock, C., Tshiananga, J. T. (2004). Differences in health determinants between international and domestic students at a German university. Journal of American College Health, 53(3), 127-132. doi: https://doi.org/10.3200/JACH.53.3.127$\underline{132}$ 
Kriska, A. M. \& Caspersen, C. J. (1997). Aerobics Center Longitudinal Study Physical Activity Questionnaire. Introduction to a Collection of Physical Activity Questionnaires. Medicine \& Science in Sports \& Exercise, 29(6), 5-9.

Lochbaum, M. R., Lutz, R. S., Sell, S., Ready, A., \& Carson, T. (2004). Perceived stress and health complaints: an examination of the moderating roles of personality and physical activity. Perceptual and motor skills, 99(3), 909-912. doi: https://doi.org/10.2466/pms.99.3.909-912

Misra, R., \& Castillo, L. G. (2004). Academic stress among college students: Comparison of American and international students. International Journal of stress management, 11(2), 132-148. doi: https://doi. org/10.1037/1072-5245.11.2.132

Nguyen-Michel, S. T., Unger, J. B., Hamilton, J., \& Spruijt-Metz, D. (2006). Associations between physical activity and perceived stress/hassles in college students. Stress and Health: Journal of the International Society for the Investigation of Stress, 22(3), 179-188. doi: https://doi.org/10.1002/smi.1094

Norkus, A., \& Alūzas, R. (2012). Studentų sveikatos ugdymas Lietuvos aukštosiose mokyklose: galimybès ir problemos. Studijos šiuolaikinèje visuomenèje. Mokslo darbai, 3(1), 185-194.

Oswalt, S. B., \& Riddock, C. C. (2007). What to do about being overwhelmed: Graduate students, stress and university services. College Student Affairs Journal, 27(1), 24-44.

Poteliūnienè, S. (2010). Studentų fizinị ugdymą ir sportininkų rengimą skatinantys veiksniai. Apžvalga.
Socialiniai mokslai, edukologija (07S), 4-29. Vilnius: Vilniaus Pedagoginio universiteto leidykla.

Smith, M. A., \& Lynch, W. J. (2012). Exercise as a potential treatment for drug abuse: evidence from preclinical studies. Frontiers in psychiatry, 2, 82. doi: https://doi.org/10.3389/fpsyt.2011.00082

Stock, C., \& Kramer, A. (2001). The health of students during their education. Gesundheiitswesen (Bundesverband der Arzte des Offentlichen Gesundheitsdienstes (Germany), 63(1), 56-59. doi: https://doi.org/10.1055/s-2001-12116

Suresh, P., Matthews, A., \& Coyne, I. (2013). Stress and stressors in the clinical environment: a comparative study of fourth-year student nurses and newly qualified general nurses in Ireland. Journal of clinical nursing, 22(5-6), 770-779. doi: https://doi.org/10.1111/ j.1365-2702.2012.04145.x

Valintėlienè, R., Varvuolienè, R., \& Kranauskas, A. (2012). Lietuvos gyventojų fizinis aktyvumas, vertinant GPAQ metodu. Visuomenès sveikata, 4(59), 67-75. Retrieved from http://hi.simplit.lt/uploads/ pdf/visuomenes $\% 20$ sveikata/2012.4(59)/VS\%20 2012 4(59) Valinteliene.pdf

Vaščila, V., Siaurodinas, A., Vyskupaitis, E., Raupelis, A. (2007). Jaunimo sveikatos savianalizè ir sveika elgsena. Ugdymas. Kūno kultūra. Sportas, 2, 250-254.

Zschucke, E., Renneberg, B., Dimeo, F., Wüstenberg, T., \& Ströhle, A. (2015). The stress-buffering effect of acute exercise: Evidence for HPA axis negative feedback. Psychoneuroendocrinology, 51,414-425. doi: https://doi.org/10.1016/j.psyneuen.2014.10.019 